\title{
How We Evaluate Postgraduate Medical E-Learning: Systematic Review
}

Robert de Leeuw ${ }^{1,2}$, MSc, MD; Anneloes de Soet ${ }^{2}$, BSc; Sabine van der Horst ${ }^{2}$, BSc; Kieran Walsh ${ }^{3}$, MD, PhD; Michiel Westerman ${ }^{4}, \mathrm{MD}, \mathrm{PhD}$; Fedde Scheele ${ }^{1}, \mathrm{MD}, \mathrm{PhD}$

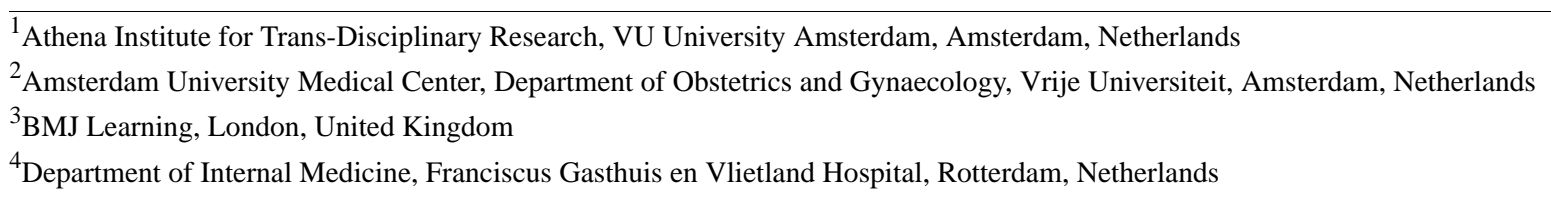

Corresponding Author:

Robert de Leeuw, MSc, MD

Athena Institute for Trans-Disciplinary Research

VU University Amsterdam

De Boelelaan 1118

Amsterdam, 1081HZ

Netherlands

Phone: 31618390269

Email: r.deleeuw@vumc.nl

\section{Abstract}

Background: Electronic learning (e-learning) in postgraduate medical education has seen a rapid evolution; however, we tend to evaluate it only on its primary outcome or learning aim, whereas its effectiveness also depends on its instructional design. We believe it is important to have an overview of all the methods currently used to evaluate e-learning design so that the preferred method may be identified and the next steps needed to continue to evaluate postgraduate medical e-learning may be outlined.

Objective: This study aimed to identify and compare the outcomes and methods used to evaluate postgraduate medical e-learning.

Methods: We performed a systematic literature review using the Web of Science, PubMed, Education Resources Information Center, and Cumulative Index of Nursing and Allied Health Literature databases. Studies that used postgraduates as participants and evaluated any form of e-learning were included. Studies without any evaluation outcome (eg, just a description of e-learning) were excluded.

Results: The initial search identified 5973 articles, of which we used 418 for our analysis. The types of studies were trials, prospective cohorts, case reports, and reviews. The primary outcomes of the included studies were knowledge, skills, and attitude. A total of 12 instruments were used to evaluate a specific primary outcome, such as laparoscopic skills or stress related to training. The secondary outcomes mainly evaluated satisfaction, motivation, efficiency, and usefulness. We found 13 e-learning design methods across 19 studies (4\% 19/418). The methods evaluated usability, motivational characteristics, and the use of learning styles or were based on instructional design theories, such as Gagne's instructional design, the Heidelberg inventory, Kern's curriculum development steps, and a scale based on the cognitive load theory. Finally, 2 instruments attempted to evaluate several aspects of a design, based on the experience of creating e-learning.

Conclusions: Evaluating the effect of e-learning design is complicated. Given the diversity of e-learning methods, there are many ways to carry out such an evaluation, and probably, many ways to do so correctly. However, the current literature shows us that we have yet to reach any form of consensus about which indicators to evaluate. There is a great need for an evaluation tool that is properly constructed, validated, and tested. This could be a more homogeneous way to compare the effects of e-learning and for the authors of e-learning to continue to improve their product.

(JMIR Med Educ 2019;5(1):e13128) doi: 10.2196/13128

\section{KEYWORDS}

distance education; learning; professional education 


\section{Introduction}

\section{Background}

Electronic learning (e-learning) in postgraduate medical education has seen a rapid evolution [1,2]. Moreover, e-learning has become a central part of education, whether stand-alone, part of hybrid learning, or an essential element in the successful flipped classroom concept [3-5].

Although postgraduate medical e-learning (PGMeL) is becoming part of mainstream education, its effectiveness has been subject to debate. A Cochrane review from 2018 concludes that comparing e-learning with traditional learning seems to reveal little to no difference [6]. Yet, other studies show great benefits with regard to primary outcomes $[7,8]$ or secondary aspects such as environmental impact [9].

A possible reason for this discrepancy can be the heterogeneity in instructional design and other elements of e-learning that are poorly evaluated [10]. PGMeL is frequently evaluated by means of a pre- and posttest of the primary learning aim (eg, new knowledge) [11]. However, every educational instrument has functionalities and elements that are used to optimize its effect. The elements required for a specific e-learning model are defined in the so-called instructionaldesign. These elements are also called affordances and have the purpose of maximizing the effect, effectiveness, and usefulness of an educational instrument [12]. Therefore, the affordance of an instrument is an action made possible by the availability of that tool (eg, interactive videos) [13]. Although several reviews of the effects of e-learning have been carried out, little has been written about the ways in which an e-learning's instructional design may be evaluated [6,14]. A valuable introduction to the design of e-learning was given by Ellaway and Masters, who provide certain guidelines but no method of evaluation [15]. We believe it is of great importance to have a better insight into the current PGMeL evaluation methods and which outcomes (primary or secondary) are used. The aim of this study was to provide an overview of the outcomes used to evaluate PGMeL and the evaluation methods of the models used. To do so, we first need to provide a working definition of e-learning for this review.

\section{Electronic Learning Definitions}

The definition of e-learning changed with the evolution of the internet, and most definitions fail to describe the subtleties and certain important aspects of e-learning. It does not simply consist of placing documents in an electronic format via the internet. It should encourage interaction, collaboration, and communication, often asynchronously [15]. For this literature review, we have chosen the following, slightly adapted, definition from the study by Sangra et al [16]:

\section{E-learning is an approach to teaching and learning, representing all or part of the educational model applied, that is based on the use of electronic media and devices as tools for improving access to training, communication and interaction and that facilitates the adoption of new knowledge, skills and/or behaviour/attitude.}

\section{Methods}

\section{Study Design}

A systematic review was carried out to determine how PGMeL can be evaluated and which outcomes are used. Some studies compared e-learning with other learning methods in trials or cohorts, whereas others were conducted from case reports by authors who evaluated a newly used e-learning method alone. We followed all the steps laid out in the Preferred Reporting Items for Systematic Reviews and Meta-Analyses (PRISMA) guidelines because the risk of bias is not relevant in answering our question [17]; given that we are not looking at the results of the outcomes but, rather, at the content of the outcomes themselves, we did not evaluate the risk of bias.

\section{Types of Studies and Participants}

The types of studies included are trials, reviews, and other descriptive evaluation studies as well as all the studies that evaluated any form of e-learning, as defined above, that have postgraduate medical professionals as a target audience.

\section{Study Eligibility}

The inclusion criteria were as follows:

1. Any e-learning evaluation study (studies without any evaluation outcome were excluded)

2. Postgraduate target audience for the e-learning

3. Published in English

4. Published after the introduction of Web 1.0 (1994)

\section{Type of Intervention and Outcomes}

The type of intervention was any form of e-learning, as discussed in the introduction. Given that the purpose of this review was to overview the kinds of outcomes used, all outcomes were included. We differentiated between primary and secondary outcomes. A primary outcome was defined if the study described the outcome as a primary outcome, if a sample size was calculated based on that outcome, or when the authors defined the outcome in the research question. If it was not clear what the primary outcome was, all outcomes were used as primary outcomes.

\section{Study Identification}

The literature search was performed in November 2017, searching PubMed, Education Resources Information Center, Cumulative Index of Nursing and Allied Health Literature and Web of Science databases separately. The search string was quite extensive and used a combination of Medical Subject Headings terms and a combination of title and abstract keywords. The complete string may be found in Multimedia Appendix 1.

\section{Study Selection}

Working independently and in duplicate, reviewers (RDL, ADS, and SVH) screened all article titles and abstracts. Potentially eligible abstracts and abstracts with disagreement or insufficient information were screened in full text. Disagreements were handled by discussing the full text and the majority counts. The dataset supporting the conclusions of this study is available in the Postgraduate ME Model repository [18]. 


\section{Results}

\section{Search Results}

The initial search identified 5973 articles, of which 4691 were left after removing all duplicates. The titles and abstracts were read to determine the relevance, outcomes, and target audience. After handsearching and snowballing, 824 possible studies remained for review. After reading the full texts of these articles, we rejected 406 as not being targeted at the right audience or not evaluating the e-learning but only describing it. We used 418 final articles for our analysis, as shown in the flow diagram in Figure 1, which all evaluated an educational intervention that satisfied our definition of e-learning. For a list of all 418 studies, please refer to Multimedia Appendix 2.

Figure 1. Search and article selection process. e-learning: electronic learning; CINAHL: Cumulative Index of Nursing and Allied Health Literature; ERIC: Education Resources Information Center.

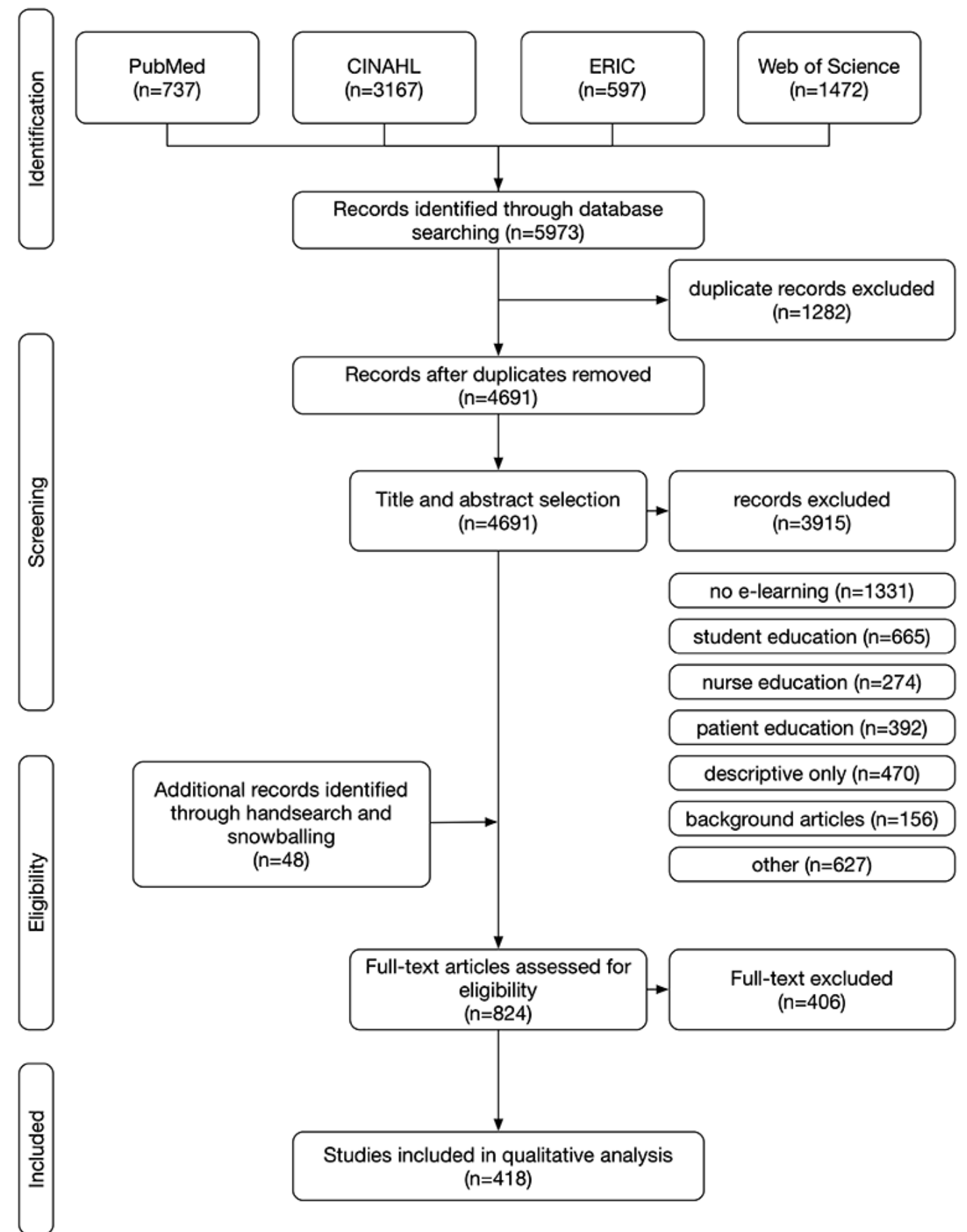




\section{General Characteristics}

The types of studies were trials $(n=201)$, prospective cohorts $(n=110)$, case reports $(n=98)$, and reviews $(n=9)$. We found a variation of e-learning methods and combined these into 4 categories: serious gaming $(n=8)$, virtual reality $(n=90)$, simulation $(\mathrm{n}=79)$, and theoretical knowledge-aimed e-learning $(n=241)$. We added augmented reality into the virtual reality group (Figure 2). Most of the e-learning was created for general medicine $(n=86)$, followed by surgery $(n=84)$, internal medicine $(n=59)$, pediatrics $(n=32)$, gynecology $(n=28)$, and family medicine ( $n=23$; Figure 3$)$. Studies were grouped under general medicine when they were multidisciplinary. A group of 16 studies had no specified target audience. Family medicine was grouped together with primary care.

Figure 2. Types of electronic learning (\%). Knowledge refers to any acquaintance with facts, truths, or principles. Simulation refers to any form of digital imitation of enactment that is not virtual reality. Virtual reality refers to a simulation of a 3-dimensional environment, experienced or controlled by movement of the body. Serious gaming refers to a learning environment with gamification elements aimed at learning rather than entertainment. e-learning: electronic learning.

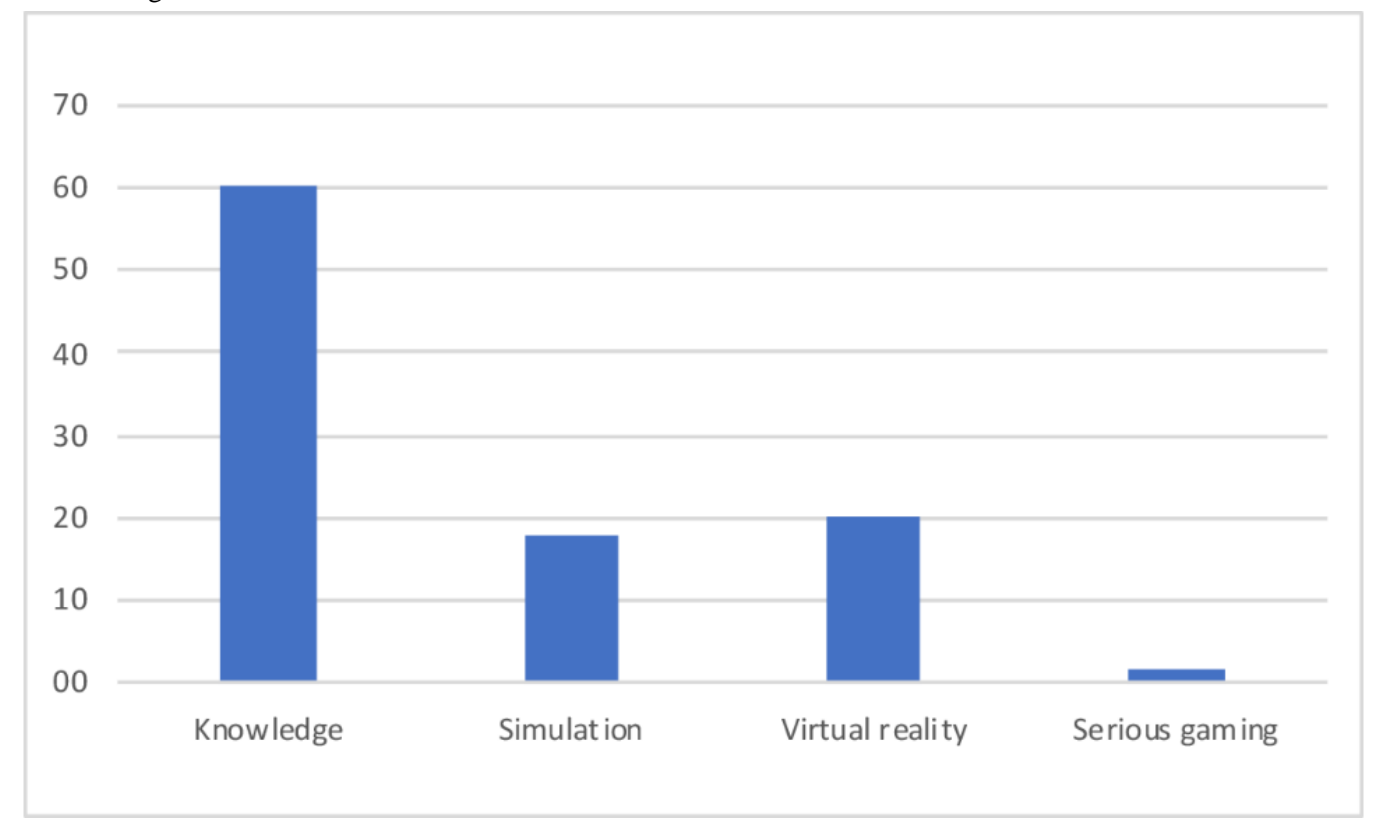

Figure 3. Electronic learning by medical subject (\%).

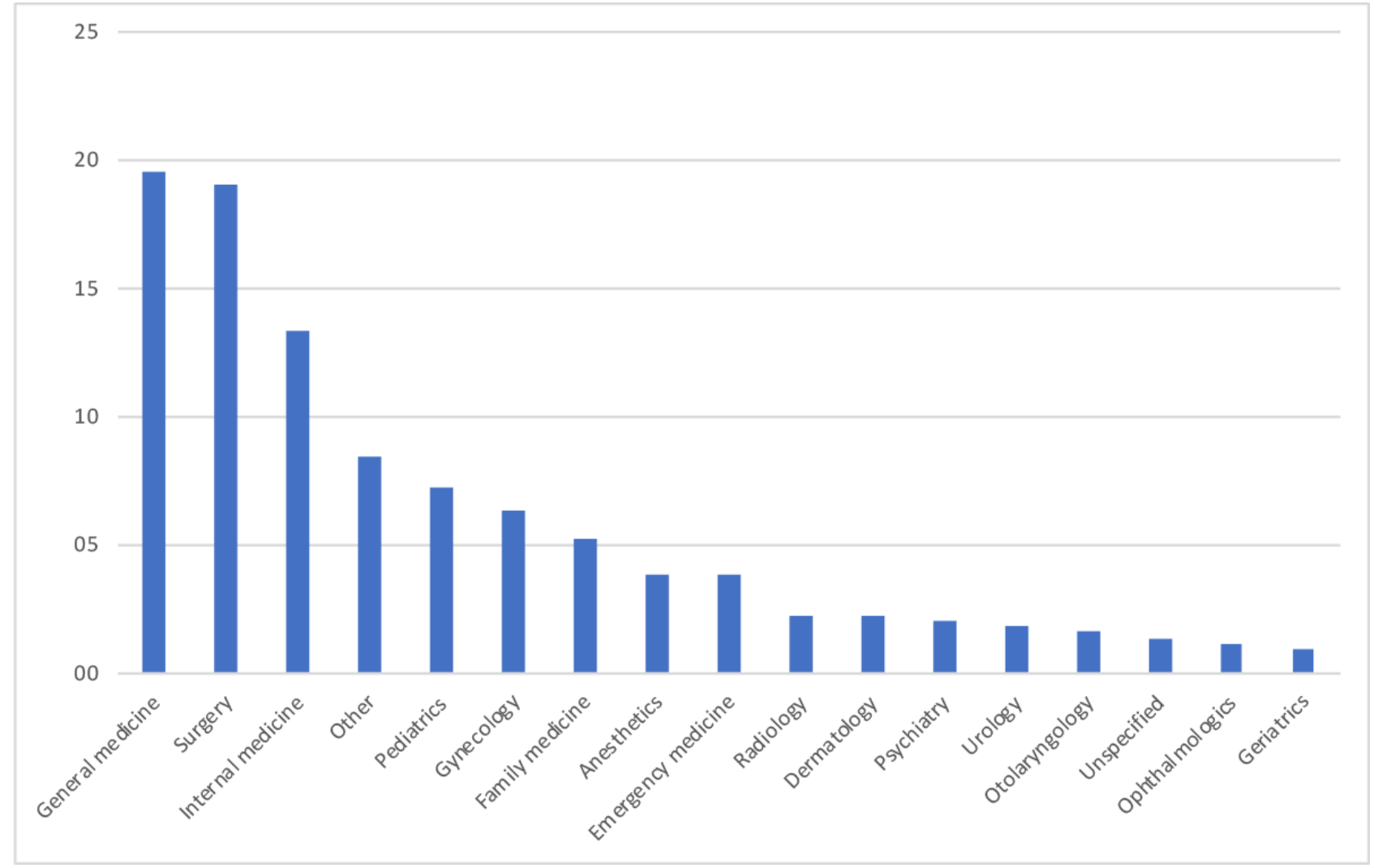




\section{Study Outcomes}

The learning aims of the included studies were knowledge $(n=286)$, skills $(n=130)$, and attitude $(n=2)$, which reflected the primary outcomes. Knowledge was tested by pre- and postcourse tests, and 12 instruments were used to evaluate an e-learning-specific primary outcome (see Table 1), such as laparoscopic skills or stress related to training.

The secondary outcomes of the studies were both more diverse and more focused on the design (see Table 2). The most prevalent evaluated outcomes were satisfaction $(n=99)$, self-efficacy $(n=60)$, adherence in practice $(n=33)$, and time spent $(n=32)$. Overall, 28 studies had some sort of qualitative evaluation, such as focus discussions or personal interviews. To prevent too diverse a series of outcomes, we grouped comparable outcomes together. Therefore, satisfaction can be measured by using a Likert scale but also by asking if someone would recommend the e-learning to other residents. Adherence in practice can be self-reported practice change or objective changes in practice, for example, subscription practice. We used the term self-efficacy for each form of self-assessed confidence, understanding, or comfort in clinical or theoretical settings.

A total of 5 studies used Kirkpatrick's levels of evaluation. These levels were more used as secondary outcomes of the learning aim than as a design evaluation method [29,33-36]. Kirkpatrick described a 4-level framework of evaluation for measuring the effectiveness of training or human performance technology programs originally aimed at corporate human resources [37]. The levels are reaction, learning, behavior, and results. Aitken et al evaluated their radiology e-learning material based on the first 2 levels, using the framework to build an evaluation questionnaire [34]. Sim et al focused on learning, behavior change, and impact on workplace by quantitative pre-, mid- and postmodule surveys; qualitative Wseb-based discussions; and short facilitator meetings [33]. In 2016, Bowe et al evaluated their e-learning program by means of the Kirkpatrick framework, but a narrative review provided them with the 3 other evaluation tools discussed below as well [29]. Finally, Patel et al undertook a review to establish the effectiveness of simulation in interventional radiology and evaluated which level of Kirkpatrick's hierarchy the studies reached, with only 1 reaching level 4 . No proper validation of PGMeL has been carried out, and there are many concerns about the overgeneralization and misunderstandings that compromise its evaluation [38]. One study by Sears et al [39] used Robert and McDonald's revision of Kirkpatrick's levels, where the third and fourth levels fall into an overall practice domain and a new level, value, is added to better suit current technologies and continuing education approaches.

\section{Electronic Learning Design Evaluation Methods and Theories}

Overall, 19 studies (4\%) used some form of tool to evaluate the e-learning design, and 13 tools were described in these studies. These 19 studies alone provided us with the methods and theories at which our initial research question was aimed.

Two instruments focused on usability, namely, the System Usability Scale (SUS) and the Software Usability Measurement Inventory (SUMI).

\section{The System Usability Scale $(n=5)$}

This is a 10-item questionnaire developed by Brooke that measures the usability of computer systems in 3 domains: effectiveness, efficiency, and satisfaction. It has been freely available since 1986 and has been cited in more than 1200 publications [40]. Davids et al used the SUS first to evaluate an e-learning resource for electrolyte and acid-base disorders [41] and again in 2014 to evaluate the effect of improving usability [42]. The SUS was also used by Gorrindo et al [43], Diehl et al [44], and Gillespie in 2017 [45].

Table 1. Discipline of skill-specific outcome measurement tools.

\begin{tabular}{|c|c|c|}
\hline Name & Evaluation topic & Reference \\
\hline Vandenberg and Kuse mental rotations test & Laparoscopic skills & Ahlborg [19] \\
\hline Arthroscopic Surgery Skill Evaluation Tool & Arthroscopic skills & Waterman [20] \\
\hline Stanford Microsurgery and Resident Training Scale & Microsurgery skills & Satterwhite [21] \\
\hline Global Operative Assessment of Laparoscopic Skills & Laparoscopic skills & Rinewalt [22] \\
\hline McGill Inanimate System for Training and Evaluation of Laparoscopic Skills & Laparoscopic skills & Martinez [23] \\
\hline Objective Structured Assessment of Technical Skills & Laparoscopic skills & Tomaz [24] \\
\hline Evaluating the attitude toward research tests & Attitude toward testing & Pelayo [25] \\
\hline $\begin{array}{l}\text { Survey of Attitudes toward Achieving Competency in Practice-Based Learning and } \\
\text { Improvement and System-Based Practice }\end{array}$ & $\begin{array}{l}\text { Managed care competencies and } \\
\text { attitude }\end{array}$ & Yedidia $[26]$ \\
\hline Attitude, belief, and Behavior survey regarding domestic violence & Attitude to domestic violence & Harris [27] \\
\hline State-Trait Anxiety Inventory & Stress & Samakar [28] \\
\hline Mini-Mental State Exam & Stress & Tomaz [24] \\
\hline Attitude Toward Health Care Teams Scale & Teamwork & Bowe [29] Leipzig [30] \\
\hline Assessment of Care for the Vulnerable Elderly & Elderly care & Holmboe [31] \\
\hline Cumulative sum analysis for colorectal histology & Histology & Patel [32] \\
\hline
\end{tabular}


Table 2. Secondary outcomes.

\begin{tabular}{|c|c|}
\hline Outcome & Statistics, n (\%) \\
\hline Satisfaction & $88(19.9)$ \\
\hline Self-efficacy & $60(13.6)$ \\
\hline Adherence in practice & $31(7.0)$ \\
\hline Long-term follow-up & $28(6.3)$ \\
\hline Qualitative evaluation & $28(6.3)$ \\
\hline Time spent & $27(6.1)$ \\
\hline Skills & $25(5.7)$ \\
\hline Attitude & $20(4.5)$ \\
\hline Usefulness & $16(3.6)$ \\
\hline Efficiency & $8(1.8)$ \\
\hline Confidence & $8(1.8)$ \\
\hline Usability & $8(1.8)$ \\
\hline Acceptability & $6(1.4)$ \\
\hline Preference & $6(1.4)$ \\
\hline Costs & $5(1.1)$ \\
\hline Presentation quality & $5(1.1)$ \\
\hline Knowledge & $4(0.9)$ \\
\hline Motivation & $4(0.9)$ \\
\hline Stress & $3(0.7)$ \\
\hline Patient satisfaction & $2(0.5)$ \\
\hline Agreement & $1(0.2)$ \\
\hline Discomfort & $1(0.2)$ \\
\hline Overall reaction & $1(0.2)$ \\
\hline Participation & $1(0.2)$ \\
\hline Readiness to change & $1(0.2)$ \\
\hline Screening percentage & $1(0.2)$ \\
\hline Cognitive load & $1(0.2)$ \\
\hline
\end{tabular}

\section{The Software Usability Measurement Inventory (n=1)}

According to Deraniyagala et al, there are multiple approaches to measuring usability, but the gold standard is the SUMI because of its extensive validations and long track record of success in evaluation [46]. It consists of a 50-item questionnaire devised in accordance with psychometric practice and was inspired by the 1993 ISO 9241 definition by Kiralowski and Corbett [47].

A total of 3 instruments attempted to evaluate the motivational characteristics of the design.

\section{The Motivated Strategies for Learning Questionnaire $(\mathbf{n}=\mathbf{1})$}

Ahlborg et al used a few items from the Motivated Strategies for Learning Questionnaire to evaluate self-efficacy [19] and Cook et al validated the entire questionnaire [48]. It consists of a self-reported, Likert scale instrument developed by Pintrich et al in 1993, which aims to assess the motivation and use of learning strategies by college students [49]. Cook et al concluded that the scores are reliable and offer meaningful outcomes for residents in a Web-based course.

\section{Keller's Instructional Attention, Relevance, Confidence, and Satisfaction Motivation Model $(n=2)$}

This proposes to assess the motivational characteristics of instructional materials or courses using an Attention, Relevance, Confidence, and Satisfaction (ARCS) model of motivation and was validated by Cook et al with 124 internal medicine residents [50]. Although the data were limited, they support the validity of the survey. Kawamura et al used the system as well to determine factors of motivation in serious gaming [51].

\section{Instructional Materials Motivation Survey $(\mathbf{n}=1)$}

Cooke et al validated the Instructional Materials Motivation Survey (IMMS) to assess the motivational characteristics of a course [50]. The IMMS is an instrument developed by Keller using his ARCS model. The aim of the tool is to improve a 
course design generally or to adapt a course to an individual's needs.

The 2 scales focused on the use of learning styles as described in the following sections.

\section{The Learning Style Index $(n=2)$}

The Learning Style Index [52,53], developed in 1988 by Richard Felder and Linda Silverman, is designed to capture the most important learning style of engineering students, differentiated by 4 dimensions (active-reflective, visual-verbal, sensing-intuitive, and sequential-global) [54]. Cook et al evaluated whether the preferred learning style had any effect on a Web-based course and questions. Cognitive and learning styles had no apparent influence on learning outcomes [53].

\section{Riding's Cognitive Style Analysis $(n=1)$}

Riding's Cognitive Style Analysis (RCSA) determines whether an individual has a particular cognitive style or a preferred way of processing information [53]. The RCSA test measures the cognitive style on a verbal-imagery dimension and a holistic-analytic dimension [55].

A total of 4 tools were based on previous instructional design theories: Gagne's instructional design, the Heidelberg inventory, Kern's curriculum development steps, and a scale based on cognitive load theory.

\section{Gagne's Events Instructions ( $\mathbf{n}=\mathbf{1}$ )}

The instructional design by Gagne et al has been a classic in learning since 1974 and is a general, instructional design theory [56]. It has 9 parts, mirroring Gagne's idea of the cognitive stages associated with adult learning [57]. The model is used as a framework for designing any adult education instrument.

\section{Heidelberg Inventory for the Evaluation of Teaching $(\mathbf{n}=\mathbf{1})$}

The Heidelberg Inventory for the Evaluation of Teaching [58] is a. standardized, psychometric questionnaire for the didactic quality assessment of the whole program. It consists of 13 domains and 42 items/questions and was developed to evaluate teaching methods for German undergraduate students [59].

\section{Kern's 6-Step Curriculum Development for Medical Education (n=1)}

This approach [60], described by Kern et al in 2009, aimed to create a planned educational experience with a logical, systematic approach [61].

\section{Learner's Scale $(n=1)$}

This series of scales [62] is composed of learner satisfaction, self-efficacy, mental effort, and time on task. The questions used for these scales are based on cognitive load principles and multimedia learning, which are based on the work by Clark and Mayer [63] and van Merrienboer [64].

Finally, 2 instruments attempted to evaluate several aspects of a design, based on the experience of creating e-learning.

\section{The 10 Golden Rules for Software Design (n=2)}

Created to help in designing software in medical education, this $[36,65]$ starts with a 51-item questionnaire based on the Context, Input, Process, and Product model by Stufflebeam [66]; the Convenience, Relevance, Individualization, Self-assessment, Interest, Speculation, and Systematic criteria [67]; and Kirkpatrick's 4 levels of evaluation. The questionnaire was then piloted and used to evaluate an interactive distance education course in obstetrics and gynecology [36]. From the qualitative data, 10 common items were identified and represented in the form of 10 golden rules.

\section{Quality Improvement Knowledge Application Tool-Revised $(\mathbf{n}=\mathbf{1})$}

A revision of the original Quality Improvement Knowledge Application Tool, validated to assess practice-based learning and the system-based practice of residents, the Quality Improvement Knowledge Application Tool-Revised (QIKATR) $[29,68]$ consists of 3 subjects - aim, measure, and change-and participants are asked to score the presented scenarios on these subjects.

Apart from these evaluation methods, we found 4 studies that did not evaluate e-learning but did use evaluation methods to create their e-learning. These used instruments to create e-learning with a focus on outcomes, motivation, and technology acceptance:

\section{The Formative Process and Outcome Evaluation Tool by Dunet}

Dunet et al [69] described the evaluation process by which they created a course - formative evaluation (content and design), process evaluation (knowledge gain, motivation, and usefulness), and outcome evaluation.

\section{The Website Motivational Analysis Checklist}

The authors reviewed an education database and did not find any validated tools. Therefore, they used the Website Motivational Analysis Checklist [70], which was originally created to assess service-based commercial websites in 2000 [71].

\section{Davis's Technology Acceptance Model and Laurillard's Model of Interactive Dialogue}

A realistic review by Wong et al [72] identified these 2 main theories as having a significant focus on perceived advantage, ease of use, interactivity, and feedback.

Finally, Rosen et al describe a statistical tool to apply to the study of teleoperation, human manipulation actions, and manufacturing applications (Hidden Markov Model), which they suggest might also be useful for other evaluation methods [73].

The abovementioned evaluation models all evaluate certain domains, a summary of which is presented in Tables 3 and 4 as an overview. In the final column, we have added the domains evaluated by de Leeuw et al in previous studies [74]. 
Table 3. Domains and methods for evaluating postgraduate medical electronic learning design (part 1).

\begin{tabular}{|c|c|c|c|c|c|c|c|c|}
\hline Factor & $\begin{array}{l}\text { Riding's Cogni- } \\
\text { tive Style Analy- } \\
\text { sis }\end{array}$ & $\begin{array}{l}\text { Kern's six } \\
\text { steps }\end{array}$ & $\begin{array}{l}\text { Motivated } \\
\text { Strategies } \\
\text { For Learning } \\
\text { Question- } \\
\text { naire }\end{array}$ & $\begin{array}{l}\text { Software Us- } \\
\text { ability Mea- } \\
\text { surement In- } \\
\text { ventory }\end{array}$ & $\begin{array}{l}\text { Dunet } \\
\text { model }\end{array}$ & $\begin{array}{l}\text { Website Mo- } \\
\text { tivational } \\
\text { Analysis } \\
\text { Checklist }\end{array}$ & $\begin{array}{l}\text { Davis's } \\
\text { model }\end{array}$ & $\begin{array}{l}\text { de Leeuw } \\
\text { quality indi- } \\
\text { cators }\end{array}$ \\
\hline Learning aims/objectives & $-^{\mathrm{a}}$ & $x^{b}$ & $\mathrm{x}$ & - & $\mathrm{X}$ & $\mathrm{X}$ & $\mathrm{X}$ & $\mathrm{x}$ \\
\hline Measurement of performance & - & $\mathrm{x}$ & $\mathrm{X}$ & - & $\mathrm{x}$ & - & - & $\mathrm{x}$ \\
\hline Aim for change/transfer to the job & - & $\mathrm{X}$ & - & - & $\mathrm{X}$ & - & - & $\mathrm{X}$ \\
\hline Satisfaction & - & - & - & $\mathrm{x}$ & $\mathrm{x}$ & - & - & $\mathrm{x}$ \\
\hline Usability and control & - & - & - & $\mathrm{x}$ & $\mathrm{x}$ & $\mathrm{x}$ & $\mathrm{x}$ & $\mathrm{x}$ \\
\hline Integration or recall of prior learning & - & $\mathrm{x}$ & $\mathrm{x}$ & - & $\mathrm{x}$ & - & - & $\mathrm{x}$ \\
\hline Confidence & - & - & - & - & $\mathrm{x}$ & - & - & $\mathrm{x}$ \\
\hline $\begin{array}{l}\text { Suitability/usefulness/relevance/help- } \\
\text { fulness }\end{array}$ & - & $\mathrm{X}$ & $\mathrm{X}$ & $\mathrm{x}$ & $\mathrm{x}$ & $\mathrm{X}$ & $\mathrm{x}$ & $\mathrm{x}$ \\
\hline Attention & - & - & $\mathrm{x}$ & - & - & - & - & $\mathrm{x}$ \\
\hline Sensing or intuitive learning & $\mathrm{X}$ & - & - & - & - & - & - & - \\
\hline Visual or verbal learning & $\mathrm{x}$ & - & - & - & - & - & - & - \\
\hline Active or reflective learning & $\mathrm{X}$ & - & - & - & - & - & - & - \\
\hline Sequential or global learning & $\mathrm{X}$ & - & - & - & - & - & - & - \\
\hline Content accountability & - & - & - & - & $\mathrm{x}$ & $\mathrm{x}$ & - & $\mathrm{X}$ \\
\hline Multimedia use & - & $\mathrm{x}$ & - & - & $\mathrm{x}$ & $\mathrm{x}$ & - & $\mathrm{x}$ \\
\hline Problem-based setting & - & - & $\mathrm{x}$ & - & - & - & - & $\mathrm{x}$ \\
\hline Impetus for use/motivation & - & $\mathrm{x}$ & $\mathrm{x}$ & $\mathrm{x}$ & $\mathrm{X}$ & $\mathrm{X}$ & - & $\mathrm{X}$ \\
\hline Costs & - & - & - & - & - & - & - & $\mathrm{x}$ \\
\hline Feedback and interactivity & - & $\mathrm{x}$ & $\mathrm{x}$ & - & - & $\mathrm{x}$ & $\mathrm{x}$ & $\mathrm{x}$ \\
\hline Challenge & - & & $\mathrm{x}$ & - & - & $\mathrm{x}$ & - & $\mathrm{X}$ \\
\hline Commitment and maintenance & - & $\mathrm{x}$ & $\mathrm{X}$ & - & - & - & - & $\mathrm{x}$ \\
\hline Implementation & - & $\mathrm{x}$ & - & - & $\mathrm{x}$ & - & - & $\mathrm{x}$ \\
\hline Rehearsal & - & - & $\mathrm{x}$ & - & - & - & - & $\mathrm{x}$ \\
\hline Time management & - & - & $\mathrm{x}$ & - & $\mathrm{x}$ & - & - & $\mathrm{x}$ \\
\hline Tasks & - & - & $\mathrm{x}$ & - & - & - & - & $\mathrm{x}$ \\
\hline Efficiency & - & - & - & $\mathrm{x}$ & - & - & - & $\mathrm{x}$ \\
\hline User expectation & - & - & - & - & - & - & $\mathrm{x}$ & - \\
\hline
\end{tabular}

${ }^{\mathrm{a}}$ Factor present in the model.

${ }^{\mathrm{b}}$ Factor not present in the model. 
Table 4. Domains and methods for evaluating postgraduate medical electronic learning design (part 2).

\begin{tabular}{|c|c|c|c|c|c|c|c|c|}
\hline Factor & $\begin{array}{l}\text { Quality Improve- } \\
\text { ment Knowledge } \\
\text { Application Tool- } \\
\text { Revised (model of } \\
\text { improvement) }\end{array}$ & $\begin{array}{l}\text { System } \\
\text { Usability } \\
\text { Scale }\end{array}$ & $\begin{array}{l}\text { Instructional } \\
\text { Materials } \\
\text { Motivation } \\
\text { Survey }\end{array}$ & $\begin{array}{l}\text { Attention, } \\
\text { Relevance, } \\
\text { Confidence, } \\
\text { and Satisfac- } \\
\text { tion motiva- } \\
\text { tion model }\end{array}$ & $\begin{array}{l}\text { Index of } \\
\text { learning } \\
\text { styles }\end{array}$ & $\begin{array}{l}10 \text { golden } \\
\text { rules }\end{array}$ & $\begin{array}{l}\text { Gagne's } \\
\text { events in- } \\
\text { structions }\end{array}$ & $\begin{array}{l}\text { Heidelberg in- } \\
\text { ventory for the } \\
\text { evaluation of } \\
\text { teaching }\end{array}$ \\
\hline Learning aims/objectives & $x^{a}$ & $-\mathrm{b}$ & - & - & - & $\mathrm{x}$ & $\mathrm{x}$ & $\mathrm{x}$ \\
\hline Measurement of performance & $\mathrm{x}$ & - & - & - & - & - & $\mathrm{x}$ & $\mathrm{x}$ \\
\hline $\begin{array}{l}\text { Aim for change/transfer to the } \\
\text { job }\end{array}$ & $\mathrm{x}$ & $\mathrm{x}$ & - & - & - & - & $\mathrm{x}$ & $\mathrm{x}$ \\
\hline Satisfaction & - & $\mathrm{x}$ & $\mathrm{x}$ & $\mathrm{x}$ & - & $\mathrm{x}$ & - & $\mathrm{x}$ \\
\hline Usability and control & - & $\mathrm{x}$ & - & - & - & $\mathrm{x}$ & - & $\mathrm{x}$ \\
\hline $\begin{array}{l}\text { Integration or recall of prior } \\
\text { learning }\end{array}$ & - & $\mathrm{x}$ & - & - & - & - & $\mathrm{x}$ & $\mathrm{x}$ \\
\hline Confidence & - & $\mathrm{x}$ & $\mathrm{x}$ & $\mathrm{x}$ & - & - & - & - \\
\hline $\begin{array}{l}\text { Suitability/usefulness/rele- } \\
\text { vance/helpfulness }\end{array}$ & - & $\mathrm{x}$ & $\mathrm{x}$ & $\mathrm{x}$ & - & $\mathrm{x}$ & $\mathrm{x}$ & $\mathrm{x}$ \\
\hline Attention & - & - & - & $\mathrm{x}$ & - & $\mathrm{x}$ & $\mathrm{x}$ & - \\
\hline Sensing or intuitive learning & - & - & - & - & $\mathrm{x}$ & - & $\mathrm{x}$ & - \\
\hline Visual or verbal learning & - & - & - & - & $\mathrm{x}$ & $\mathrm{x}$ & $\mathrm{x}$ & - \\
\hline Active or reflective learning & - & - & - & - & $\mathrm{x}$ & - & $\mathrm{x}$ & - \\
\hline Sequential or global learning & - & - & - & - & $\mathrm{x}$ & - & $\mathrm{x}$ & - \\
\hline Content accountability & - & - & - & - & - & $\mathrm{x}$ & $\mathrm{x}$ & $\mathrm{x}$ \\
\hline Multimedia use & - & - & - & - & - & $\mathrm{x}$ & $\mathrm{x}$ & $\mathrm{x}$ \\
\hline Problem-based setting & - & - & - & - & - & $\mathrm{x}$ & $\mathrm{x}$ & - \\
\hline Impetus for use/motivation & - & - & - & - & - & $\mathrm{x}$ & - & $\mathrm{x}$ \\
\hline Costs & - & - & - & - & - & $\mathrm{x}$ & $\mathrm{x}$ & - \\
\hline Feedback and interactivity & - & - & - & - & - & - & $\mathrm{x}$ & $\mathrm{x}$ \\
\hline Challenge & - & - & - & - & - & - & - & $\mathrm{x}$ \\
\hline Commitment and maintenance & - & - & - & - & - & - & - & $\mathrm{x}$ \\
\hline Implementation & - & - & - & - & - & - & - & - \\
\hline Rehearsal & - & - & - & - & - & - & - & - \\
\hline Time management & - & - & - & - & - & - & - & - \\
\hline Tasks & - & - & - & - & - & - & - & - \\
\hline Efficiency & - & - & - & - & - & - & - & - \\
\hline User expectation & - & - & - & - & - & - & - & - \\
\hline
\end{tabular}

${ }^{\mathrm{a}}$ Factor present in the model.

${ }^{\mathrm{b}}$ Factor not present in the model.

\section{Discussion}

\section{Principal Findings}

There are many ways to evaluate PGMeL, and evaluation is clearly focused on the outcomes of the intervention. We found 14 e-learning-specific and 3 general primary outcomes, 27 secondary outcomes, and 13 evaluations tools. More than half of the studies $(60 \%)$ had knowledge gain as their primary aim, which is almost the same finding as that in the 2016 review by
Taveira-Gomes et al [2], who looked at all kinds of education. We are looking at PGMeL only and found that $38 \%$ were simulation and virtual reality studies. This kind of e-learning was not mentioned specifically in the study by Taveira-Gomes et al but might be comparable with the skills outcome (14.6\%). The difference could be the result of postgraduates' need to undertake more task- and real-life-related e-learning, as described in our focus groups [74]. The experts from that study emphasized real-world translation as an important factor for PGMeL. Looking at the outcomes of the studies, Seagull 
identified similar domains in surgical simulation studies [75]. Self-efficacy, satisfaction, relevance/adherence in practice, and attitude are frequently used as outcomes of e-learning in both our study and that by Seagull et al. Table 1 shows a list of methods used to evaluate an outcome, which may be laparoscopic skills, attitude, or stress. They focus on the defined outcome rather than the method used to achieve it. Many other instruments are available (such as the critical thinking index [76]), but they are either not yet used in a PGMeL e-learning evaluation setting or were not revealed by our search.

Our research question asked which evaluation methods are used. As mentioned above, only $4 \%$ used a method, and of those methods, we can differentiate between theories and instruments.

Of the theories, Kirkpatrick's hierarchy is the most used to evaluate or create e-learning. A 2017 review by Patel et al evaluated the effectiveness of simulation in interventional radiology training [35]. It also found different studies using the levels of Kirkpatrick's hierarchy to establish or evaluate the success of the e-learning. Of the educational instructional theories, 2 are leading in e-learning in general and were also found in our studies: Gagne's principles of instructional design and Mayers and Clark's e-learning and the science of instruction, also referred to as Mayers' multimedia learning. Mayers and Clark base their instructions on the cognitive load theory, which provides design guidelines based on a model of human cognitive architecture. Cook et al validated a cognitive load index in 2017 [77]. The last theory from our search is from Kern's curriculum development for medical education: a 6-step approach. All these theories are either based on education in general (eg, the work of Gagne and Mayer) or medical education (eg, the work of Kirkpatrick and Kern), but none of the theories are aimed at PGMeL. They are used to evaluate PGMeL but not specifically aimed at this audience. The Heidelberg inventory for the evaluation of teaching is even aimed at undergraduate students and only used because of the lack of a better alternative [59].

Apart from these theories, some instruments focused on 1 aspect of the design. Although these instruments have a specific focus, Table 1 shows that they cover a wider range of domains. Instruments that aim to evaluate the course as a whole are QIKATR, 10 golden rules, and Dunet's formative process and outcome evaluation tool. The QIKATR is an answer to the Accreditation Council for Graduate Medical Education, which required practice-based learning and improvement. It is a description of 3 scenarios depicting quality problems. Although the domains are not very specific (describe the aim, measure the effect, and require change), they are aimed at postgraduates and provide a good basis for any education. Conversely, they are not aimed at e-learning education [68]. In 2002, Jha et al created an e-learning model for gynecology called the Distance Interactive Learning in Obstetrics and Gynaecology. They then evaluated the e-learning, and the lessons learned were described as 10 golden rules [65]. These golden rules are aimed at postgraduates and are specific to e-learning. The most significant downside of these rules is that they are based on 1 e-learning experience only; therefore, they may be incomplete or biased by the single case that created the fundament. Finally, Dunet's formative process and outcome evaluation tool is the result of an evaluation plan based on the experience of creating a hemochromatosis training course for continuing education credits and continuing nurse education. The course has been intensively evaluated by several experts, and the key findings can be summarized in 2 domains: instructional design and content, and usability and navigation. Although aimed at postgraduate education and specific to e-learning, it is based on 1 course only and might, therefore, lack important domains and items that were not available in that course.

As demonstrated in Tables 3 and 4, Gagne's science of instruction covers most of the domains. Our search did not identify any e-learning evaluation methods that are not expert opinion-based or the result of a single evaluation and aimed at PGMeL. A previous study by our group identified all these domains in literature [78], then evaluated their relevance with the focus groups [74] and an international Delphi [79]. The domains are added in the last column of Tables 3 and 4, which illustrates that all domains, except learning styles, are identified as important in these studies. The learning styles were identified in the review, but the effect of learning style-specific education is disappointing [53]. The conclusion was that it was better not to evaluate the learning style but to offer a diversity in each e-learning [74].

\section{Strengths and Limitations}

We believe that the biggest limitation is our search. Had we included papers not aimed at postgraduate education, we would have found many more papers and evaluation models. We could also have included papers that did not actually evaluate a course but only described a theoretical model. However, our research question asked not what is available but what is actually used. We also believed in differentiating between graduate and postgraduate education, hence the choice in our search. However, we also believe that making this distinction is a strength. This paper provides an insight into the diversity of evaluating e-learning and how little is known of and targeted at the right audience. Almost all quality models signify the importance of knowing your target audience but our evaluation tools do not.

\section{Conclusions}

It may be asked what comes next. We have reached the point at which we should stop evaluating only the outcomes of e-learning as an educational intervention and start evaluating the e-learning design that goes with it. However, to do so, we need a validated instrument to help us assess the nuances of all the different electronic education instruments. We believe that our previous studies have provided us with validated content for such a tool $[74,79]$ and that this paper emphasizes the need for such a system.

PGMeL is evaluated in very diverse ways, almost exclusively based on its outcomes or learning aims. Although there is a need to evaluate the e-learning itself as well, we lack the instruments to do so. This paper provides an overview of available instruments; however, they are not aimed at postgraduate medical education, not expert opinion-based, or the result of lessons learned from a single case study. With the increasing ease of creating and distributing e-learning, the need for a content-validated evaluation tool is of ever greater importance. 


\section{Acknowledgments}

This review was made possible by the help provided by Hans Ket with the search string and database selection. Special regards go to Sian Rees for proofreading the manuscript. The authors also wish to thank all the authors of the articles used in this study for their great and inspiring work.

\section{Authors' Contributions}

All authors participated in the study design and manuscript revisions. RDL performed the search with help from Hans Ket (see Acknowledgments). RDL, ADS, and SVH reviewed the search results. RDL, KW, and FS drafted the first version of the manuscript, added background data, and participated in the interpretation of the results. MW, ADS, and SVH revised the manuscript accordingly. All authors read and approved the final manuscript.

\section{Conflicts of Interest}

None declared.

\section{Multimedia Appendix 1}

Search string in detail.

[PDF File (Adobe PDF File), 261KB-Multimedia Appendix 1]

\section{Multimedia Appendix 2}

Search results (sorted by year).

[PDF File (Adobe PDF File), 270KB-Multimedia Appendix 2]

\section{References}

1. Ruiz JG, Mintzer MJ, Leipzig RM. The impact of E-learning in medical education. Acad Med 2006 Mar;81(3):207-212. [Medline: 16501260$]$

2. Taveira-Gomes T, Ferreira P, Taveira-Gomes I, Severo M, Ferreira MA. What are we looking for in computer-based learning interventions in medical education? A systematic review. J Med Internet Res 2016 Aug 01;18(8):e204 [FREE Full text] [doi: 10.2196/jmir.5461] [Medline: 27480053]

3. Jesurasa A, Mackenzie K, Jordan H, Goyder EC. What factors facilitate the engagement with flipped classrooms used in the preparation for postgraduate medical membership examinations? Adv Med Educ Pract 2017;8:419-426 [FREE Full text] [doi: 10.2147/AMEP.S132266] [Medline: 28721116]

4. Boelens R, De Wever B, Rosseel Y, Verstraete AG, Derese A. What are the most important tasks of tutors during the tutorials in hybrid problem-based learning curricula? BMC Med Educ 2015 May 06;15:84 [FREE Full text] [doi: 10.1186/s12909-015-0368-4] [Medline: 25943429]

5. Brooks HL, Pontefract SK, Vallance HK, Hirsch CA, Hughes E, Ferner RE, et al. Perceptions and impact of mandatory eLearning for foundation trainee doctors: a qualitative evaluation. PLoS One 2016;11(12):e0168558 [FREE Full text] [doi: 10.1371/journal.pone.0168558] [Medline: 28005938]

6. Vaona A, Banzi R, Kwag KH, Rigon G, Cereda D, Pecoraro V, et al. E-learning for health professionals. Cochrane Database Syst Rev 2018 Jan 21;1:CD011736. [doi: 10.1002/14651858.CD011736.pub2] [Medline: 29355907]

7. Tarpada SP, Morris MT, Burton DA. E-learning in orthopedic surgery training: a systematic review. J Orthop 2016 Dec;13(4):425-430 [FREE Full text] [doi: 10.1016/j.jor.2016.09.004] [Medline: 27688638]

8. Feng J, Chang Y, Chang H, Erdley WS, Lin C, Chang Y. Systematic review of effectiveness of situated e-learning on medical and nursing education. Worldviews Evid Based Nurs 2013 Aug;10(3):174-183. [doi: 10.1111/wvn.12005] [Medline: 23510119]

9. Walsh K. E-learning in medical education: the potential environmental impact. Educ Prim Care 2018 Dec;29(2):104-106. [doi: 10.1080/14739879.2017.1389619] [Medline: 29050529]

10. Lawn S, Zhi X, Morello A. An integrative review of e-learning in the delivery of self-management support training for health professionals. BMC Med Educ 2017 Oct 10;17(1):183 [FREE Full text] [doi: 10.1186/s12909-017-1022-0] [Medline: 29017521]

11. Taveira-Gomes T, Ferreira P, Taveira-Gomes I, Severo M, Ferreira MA. What are we looking for in computer-based learning interventions in medical education? A systematic review. J Med Internet Res 2016 Aug 01;18(8):e204 [FREE Full text] [doi: 10.2196/jmir.5461] [Medline: 27480053]

12. Khalil MK, Elkhider IA. Applying learning theories and instructional design models for effective instruction. Adv Physiol Educ 2016 Jun;40(2):147-156 [FREE Full text] [doi: 10.1152/advan.00138.2015] [Medline: 27068989] 
13. Gros B, García-Peñalvo F. Learning, Design, and Technology. 2016. Future Trends in the Design Strategies and Technological Affordances of E-Learning URL: https://repositorio.grial.eu/bitstream/grial/812/1/eLearningChapter preprint.pdf [accessed 2019-02-19] [WebCite Cache ID 76Ijh8MBL]

14. DelSignore LA, Wolbrink TA, Zurakowski D, Burns JP. Test-enhanced e-learning strategies in postgraduate medical education: a randomized cohort study. J Med Internet Res 2016 Nov 21;18(11):e299 [FREE Full text] [doi: 10.2196/jmir.6199] [Medline: 27872034]

15. Ellaway R, Masters K. AMEE Guide 32: e-Learning in medical education Part 1: Learning, teaching and assessment. Med Teach 2008 Jun;30(5):455-473. [doi: 10.1080/01421590802108331] [Medline: 18576185]

16. Sangrà V, Vlachopoulos D, Cabrera N. Building an inclusive definition of e-learning: an approach to the conceptual framework. Int Rev Res Open Dis 2012;13(2) [FREE Full text]

17. Liberati A, Altman DG, Tetzlaff J, Mulrow C, Gøtzsche PC, Ioannidis JP, et al. The PRISMA statement for reporting systematic reviews and meta-analyses of studies that evaluate health care interventions: explanation and elaboration. PLoS Med 2009 Jul 21;6(7):e1000100 [FREE Full text] [doi: 10.1371/journal.pmed.1000100] [Medline: 19621070]

18. Research Survey. URL: http://researchsurvey.nl/reviews/PGMEevaluation [accessed 2019-02-21] [WebCite Cache ID 76LWb0CB8]

19. Ahlborg L, Hedman L, Nisell H, Felländer-Tsai L, Enochsson L. Simulator training and non-technical factors improve laparoscopic performance among OBGYN trainees. Acta Obstet Gynecol Scand 2013 Oct;92(10):1194-1201. [doi: 10.1111/aogs.12218] [Medline: 24461067]

20. Waterman BR, Martin KD, Cameron KL, Owens BD, Belmont PJ. Simulation training improves surgical proficiency and safety during diagnostic shoulder arthroscopy performed by residents. Orthopedics 2016 May 1;39(3):e479-e485. [doi: 10.3928/01477447-20160427-02] [Medline: 27135460]

21. Satterwhite T, Son JI, Carey J, Echo A, Spurling T, Paro J, et al. The Stanford Microsurgery and Resident Training (SMaRT) Scale: validation of an on-line global rating scale for technical assessment. Ann Plast Surg 2014 May;72(Suppl 1):S84-S88. [doi: 10.1097/SAP.0000000000000139] [Medline: 24691332]

22. Rinewalt D, Du H, Velasco JM. Evaluation of a novel laparoscopic simulation laboratory curriculum. Surgery 2012 Oct;152(4):550-4; discussion 554. [doi: 10.1016/j.surg.2012.08.009] [Medline: 23021133]

23. Martinez AM, Espinoza DL. Laparoscopic learning evaluation over the internet. Telemed J E Health 2007 Oct;13(5):591-596. [doi: 10.1089/tmj.2006.0076] [Medline: 17999620]

24. Tomaz JB, Mamede S, Filho JM, Filho JS, van der Molen HT. Effectiveness of an online problem-based learning curriculum for training family medical doctors in Brazil. Educ Health (Abingdon) 2015;28(3):187-193 [FREE Full text] [doi: 10.4103/1357-6283.178605] [Medline: 26996643]

25. Pelayo-Alvarez M, Albert-Ros X, Gil-Latorre F, Gutierrez-Sigler D. Feasibility analysis of a personalized training plan for learning research methodology. Med Educ 2000 Feb;34(2):139-145. [Medline: 10652067]

26. Yedidia MJ, Gillespie CC, Moore GT. Specific clinical competencies for managing care: views of residency directors and managed care medical directors. J Am Med Assoc 2000 Sep 6;284(9):1093-1098. [doi: 10.1001/jama.284.9.1093] [Medline: 10974687]

27. Harris JM, Kutob RM, Surprenant ZJ, Maiuro RD, Delate TA. Can Internet-based education improve physician confidence in dealing with domestic violence? Fam Med 2002 Apr;34(4):287-292. [Medline: 12017143]

28. Samakar K, Astudillo JA, Moussavy M, Baerg J, Reeves M, Garberoglio C. SAGES: Society of American Gastrointestinal and Endoscopic Surgeons. Evaluating virtual reality simulator training on surgical residents perceptions of stress: a randomized controlled trial URL: https://www.sages.org/meetings/annual-meeting/abstracts-archive/ evaluating-virtual-reality-simulator-training-on-surgical-residents-perceptions-of-stress-a-randomized-controlled-trial/ [accessed 2019-02-21] [WebCite Cache ID 76M446z4j]

29. Bowe S, Laury A, Kepchar J, Lospinoso J. Programmatic assessment of a comprehensive quality improvement curriculum in an otolaryngology residency. Otolaryngol Head Neck Surg 2016 Dec;155(5):729-732. [doi: 10.1177/0194599816654685] [Medline: 27301903]

30. Leipzig RM, Hyer K, Ek K, Wallenstein S, Vezina ML, Fairchild S, et al. Attitudes toward working on interdisciplinary healthcare teams: a comparison by discipline. J Am Geriatr Soc 2002 Jun;50(6):1141-1148. [doi: 10.1046/j.1532-5415.2002.50274.x] [Medline: 12110079]

31. Holmboe ES, Hess BJ, Conforti LN, Lynn LA. Comparative trial of a web-based tool to improve the quality of care provided to older adults in residency clinics: modest success and a tough road ahead. Acad Med 2012 May;87(5):627-634. [doi: 10.1097/ACM.0b013e31824cecb3] [Medline: 22450173]

32. Patel SG, Rastogi A, Austin GL, Hall M, Siller BA, Berman K, et al. 355 learning curves using cumulative sum analysis (CUSUM) for the histologic characterization of diminutive colorectal polyps using a computer-based teaching module and narrow band imaging (NBI) videos: implications for resect and discard strategy. Gastrointest Endosc 2013 May;77(5):AB145. [doi: 10.1016/j.gie.2013.04.062]

33. Sim J, Radloff A. Enhancing reflective practice through online learning: impact on clinical practice. Biomed Imaging Interv J 2008 Jan;4(1):e8 [FREE Full text] [doi: 10.2349/biij.4.1.e8] [Medline: 21614319] 
34. Aitken V, Tabakov S. Evaluation of the e-Learning material developed by EMERALD and EMIT for diagnostic imaging and radiotherapy. Med Eng Phys 2005 Sep;27(7):633-639. [doi: 10.1016/j.medengphy.2005.02.010] [Medline: 16087384]

35. Patel R, Dennick R. Simulation based teaching in interventional radiology training: is it effective? Clin Radiol 2017 Mar;72(3):266.e7-266.e14. [doi: 10.1016/j.crad.2016.10.014] [Medline: 27986263]

36. Jha V, Duffy S, McAleer S. Evaluation of distance interactive learning in obstetrics and gynaecology (DIALOG). BJOG 2002 Apr;109(4):456-461 [FREE Full text] [Medline: 12013169]

37. Kirkpatrick DL. Seven keys to unlock the four levels of evaluation. Performance Improvement 2006;45(7):5-8. [doi: 10.1002/pfi.2006.4930450702]

38. Galloway DL. Evaluating distance delivery and e-learning: is Kirkpatrick's model relevant? Performance Improvement 2005;44(4):21-27 [FREE Full text]

39. Sears K, Cohen J, Drope J. Comprehensive evaluation of an online tobacco control continuing education course in Canada. J Contin Educ Health Prof 2008;28(4):235-240. [doi: 10.1002/chp.190] [Medline: 19058244]

40. Brooke J. SUS: a retrospective. JUS 2013;8(2):29-40 [FREE Full text]

41. Davids MR, Chikte UM, Halperin ML. Development and evaluation of a multimedia e-learning resource for electrolyte and acid-base disorders. Adv Physiol Educ 2011 Sep;35(3):295-306 [FREE Full text] [doi: 10.1152/advan.00127.2010] [Medline: 21908840]

42. Davids MR, Chikte UM, Halperin ML. Effect of improving the usability of an e-learning resource: a randomized trial. Adv Physiol Educ 2014 Jun;38(2):155-160 [FREE Full text] [doi: 10.1152/advan.00119.2013] [Medline: 24913451]

43. Gorrindo T, Baer L, Sanders K, Birnbaum R, Fromson J, Sutton-Skinner K, et al. Web-based simulation in psychiatry residency training: a pilot study. Acad Psychiatry 2011;35(4):232-237. [doi: 10.1176/appi.ap.35.4.232] [Medline: 21804041]

44. Diehl LA, de Souza RM, Gordan PA, Esteves RZ, Coelho IC. User assessment of "InsuOnLine," a game to fight clinical inertia in diabetes: a pilot study. Games Health J 2015 Oct;4(5):335-343. [doi: 10.1089/g4h.2014.0111] [Medline: 26287924]

45. Gillespie E, Panjwani N, Golden D, Gunther J, Chapman T, Brower J, et al. Multi-institutional randomized trial testing the utility of an interactive three-dimensional contouring atlas among radiation oncology residents. Int J Radiat Oncol Biol Phys 2017 Dec 01;98(3):547-554. [doi: 10.1016/j.ijrobp.2016.11.050] [Medline: 28262474]

46. Deraniyagala R, Amdur R, Boyer A, Kaylor S. Usability study of the EduMod eLearning program for contouring nodal stations of the head and neck. Pract Radiat Oncol 2015;5(3):169-175. [doi: 10.1016/j.prro.2014.10.008] [Medline: 25537313]

47. Kirakowski JC. SUMI: the Software Usability Measurement Inventory. BJET 1993;24(3):210-212. [doi: 10.1111/j.1467-8535.1993.tb00076.x]

48. Cook D, Thompson W, Thomas K. The Motivated Strategies for Learning Questionnaire: score validity among medicine residents. Med Educ 2011 Dec;45(12):1230-1240. [doi: 10.1111/j.1365-2923.2011.04077.x] [Medline: 22026751]

49. Pintrich P, Smith D, Garcia T, McKeachie W. Reliability and predictive validity of the Motivated Strategies for Learning Questionnaire (Mslq). Educ Psychol Meas 2016;53(3):801-813. [doi: 10.1177/0013164493053003024]

50. Cook DA, Beckman TJ, Thomas KG, Thompson WG. Measuring motivational characteristics of courses: applying Keller's instructional materials motivation survey to a web-based course. Acad Med 2009 Nov;84(11):1505-1509. [doi: 10.1097/ACM.0b013e3181baf56d] [Medline: 19858805]

51. Kawamura H, Kishimoto K, Matsuda T, Fukushima N. [A study on comparison of learning effects between a board game and a lecture about infection control]. Yakugaku Zasshi 2014;134(7):839-849 [FREE Full text] [Medline: 24989475]

52. Cook D, Thompson W, Thomas K, Thomas M, Pankratz V. Impact of self-assessment questions and learning styles in web-based learning: a randomized, controlled, crossover trial. Acad Med 2006 Mar;81(3):231-238. [Medline: 16501263]

53. Cook DA, Thompson WG, Thomas KG, Thomas MR, Pankratz VS. Impact of self-assessment questions and learning styles in Web-based learning: a randomized, controlled, crossover trial. Acad Med 2006 Mar;81(3):231-238. [Medline: 16501263]

54. Felder R. Applications, reliability and validation of the index learning styles. Int J Engng Ed 2005;21(1):103-112 [FREE Full text]

55. Peterson ED, Deary I, Austin E. The reliability of Riding's Cognitive Style Analysis test. Personality and Individual Differences 2003 Apr;34(5):881-891. [doi: 10.1016/S0191-8869(02)00116-2]

56. Gordon M, Baker P, Ratilake M. Is a short e-learning course effective at improving paediatric prescribing skills amongst UK foundation doctors? An open label randomised controlled trial. Med Educ, Supplement 2011 2011;45:14-15. [doi: 10.1111/j.1365-2923.2011.04093]

57. Gagne R, Walter W. Principles of Instructional Design 5th Edition. Boston, MA: Cengage Learning; 2004:44-46.

58. Friedl R, Höppler H, Ecard K, Scholz W, Hannekum A, Stracke S. Development and prospective evaluation of a multimedia teaching course on aortic valve replacement. Thorac Cardiovasc Surg 2006 Feb;54(1):1-9. [doi: 10.1055/s-2005-865871] [Medline: $\underline{16485180]}$

59. von Heiner R. Teaching evaluation: Introduction and overview of research and practice of course evaluation at universities with a contribution to the evaluation of computer-based teaching. (Psychology). Bürgerstraße: Verlag Empirische Pädagogik; 2009.

60. Chang TP, Pham PK, Sobolewski B, Doughty CB, Jamal N, Kwan KY, et al. Pediatric emergency medicine asynchronous e-learning: a multicenter randomized controlled Solomon four-group study. Acad Emerg Med 2014 Aug;21(8):912-919 [FREE Full text] [doi: 10.1111/acem.12434] [Medline: 25154469] 
61. Kern DT, Hughes M. Curriculum Development for Medical Education: A Six-Step Approach, 2nd edn. Baltimore: Johns Hopkins University Press; 2009.

62. Brouwers M, Makarski J, Durocher L, Levinson A. E-learning interventions are comparable to user's manual in a randomized trial of training strategies for the AGREE II. Implement Sci 2011 Jul 26;6:81 [FREE Full text] [doi: 10.1186/1748-5908-6-81] [Medline: 21791080]

63. Clark RC. e-Learning and the Science of Instruction: Proven Guidelines for Consumers and Designers of Multimedia Learning 3rd Edition. San Francisco: Pfeiffer; 2007.

64. van Merrienboer JJ, Sweller J. Cognitive load theory in health professional education: design principles and strategies. Med Educ 2010 Jan;44(1):85-93. [doi: 10.1111/j.1365-2923.2009.03498.x] [Medline: 20078759]

65. Jha V, Duffy S. 'Ten golden rules' for designing software in medical education: results from a formative evaluation of DIALOG. Med Teach 2002 Jul;24(4):417-421. [doi: 10.1080/01421590220145798] [Medline: 12193327]

66. Stufflebeam DL. The Relevance of the CIPP Model for Educational Accountability. 1971 Presented at: Annual Meeting of the American Association of School Administrators; February 24, 1971; Atlantic City, NJ.

67. Harden R, Laidlaw J. Effective continuing education: the CRISIS criteria. Med Educ 1992 Sep;26(5):408-422. [Medline: 1435382]

68. Singh M, Ogrinc G, Cox K, Dolansky M, Brandt J, Morrison L, et al. The Quality Improvement Knowledge Application Tool Revised (QIKAT-R). Acad Med 2014 Oct;89(10):1386-1391 [FREE Full text] [doi: 10.1097/ACM.0000000000000456] [Medline: 25119555]

69. Dunet D, Reyes M, Grossniklaus D, Volansky M, Blanck H. Using evaluation to guide successful development of an online training course for healthcare professionals. J Public Health Manag Pract 2008;14(1):66-75. [doi: 10.1097/01.PHH.0000303416.04604.e3] [Medline: 18091043]

70. Paixão MP, Miot HA, Wen CL. Tele-education on leprosy: evaluation of an educational strategy. Telemed J E Health 2009;15(6):552-559. [doi: 10.1089/tmj.2008.0137] [Medline: 19659411]

71. Center for Digital Literacy. CDL: A Dozen Years and Counting URL: http://digital-literacy.syr.edu/ [accessed 2019-01-16] [WebCite Cache ID 75TGZZeg4]

72. Wong G, Greenhalgh T, Pawson R. Internet-based medical education: a realist review of what works, for whom and in what circumstances. BMC Med Educ 2010;10:12 [FREE Full text] [doi: 10.1186/1472-6920-10-12] [Medline: 20122253]

73. Rosen J, Solazzo M, Hannaford B, Sinanan M. Objective laparoscopic skills assessments of surgical residents using Hidden Markov Models based on haptic information and tool/tissue interactions. Stud Health Technol Inform 2001;81:417-423. [Medline: 11317782$]$

74. de Leeuw RA, Westerman M, Scheele F. Quality indicators for learner-centered postgraduate medical e-learning. Int J Med Educ 2017 Apr 27;8:153-162 [FREE Full text] [doi: 10.5116/ijme.58ce.60aa] [Medline: 28456781]

75. Seagull FJ, Rooney DM. Filling a void: developing a standard subjective assessment tool for surgical simulation through focused review of current practices. Surgery 2014 Sep;156(3):718-722. [doi: 10.1016/j.surg.2014.04.048] [Medline: 25175506]

76. Ospina Rave BE, Brand Monsalve EG, Aristizabal Botero CA. Development of a measurement index of critical thinking in professional formation. Invest Educ Enferm 2017 Jan;35(1):69-77. [doi: 10.17533/udea.iee.v35n1a08] [Medline: 29767925]

77. Cook DA, Castillo RM, Gas B, Artino AR. Measuring achievement goal motivation, mindsets and cognitive load: validation of three instruments' scores. Med Educ 2017 Oct;51(10):1061-1074. [doi: 10.1111/medu.13405] [Medline: 28901645]

78. De Leeuw RA, Westerman M, Nelson E, Ket JC, Scheele F. Quality specifications in postgraduate medical e-learning: an integrative literature review leading to a postgraduate medical e-learning model. BMC Med Educ 2016 Dec 08;16:168 [FREE Full text] [doi: 10.1186/s12909-016-0700-7] [Medline: 27390843]

79. de Leeuw RA, Walsh K, Westerman M, Scheele F. Consensus on quality indicators of postgraduate medical e-learning: Delphi study. JMIR Med Educ 2018 Dec 26;4(1):e13 [FREE Full text] [doi: 10.2196/mededu.9365] [Medline: 29699970]

\section{Abbreviations}

ARCS: Attention, Relevance, Confidence, and Satisfaction

e-learning: electronic learning

IMMS: Instructional Materials Motivation Survey

PGMeL: postgraduate medical e-learning

QIKATR: Quality Improvement Knowledge Application Tool-Revised

SUMI: Software Usability Measurement Inventory

SUS: System Usability Scale 
Edited by G Eysenbach; submitted 13.12.18; peer-reviewed by K Masters, S Ganesh; comments to author 10.01.19; revised version received 16.01.19; accepted 30.01.19; published 05.04.19

Please cite as:

de Leeuw $R$, de Soet A, van der Horst $S$, Walsh K, Westerman M, Scheele F

How We Evaluate Postgraduate Medical E-Learning: Systematic Review

JMIR Med Educ 2019;5(1):e13128

URL: http://mededu.jmir.org/2019/1/e13128/

doi: $10.2196 / 13128$

PMID: $\underline{30950805}$

CRobert de Leeuw, Anneloes de Soet, Sabine van der Horst, Kieran Walsh, Michiel Westerman, Fedde Scheele. Originally published in JMIR Medical Education (http://mededu.jmir.org), 05.04.2019. This is an open-access article distributed under the terms of the Creative Commons Attribution License (https://creativecommons.org/licenses/by/4.0/), which permits unrestricted use, distribution, and reproduction in any medium, provided the original work, first published in JMIR Medical Education, is properly cited. The complete bibliographic information, a link to the original publication on http://mededu.jmir.org/, as well as this copyright and license information must be included. 